\title{
W czerni. Twórczość graficzna Marii Dunin-Piotrowskiej i Zygmunta Dunina
}

$\mathrm{M}$ aria Duninówna (Dunin-Piotrowska) była uczennica Władysława Skoczylasa, członkinią stowarzyszenia artystów grafików Ryt, jedną z najbardziej aktywnych i utalentowanych graficzek polskich dwudziestolecia międzywojennego, choć często krytykowaną za przesadne korzystanie z czerni jako jednego ze środków wyrazu w drzeworycie ${ }^{1}$. Jej twórczość nagle zamarła - ostatnie znane prace pochodzą z 1938 roku, a koleje losu artystki po 1939 roku okrywa cień tajemnicy. Twórczość jej młodszego brata, Zygmunta Dunina - grafika, rysownika, karykaturzysty do tej pory w ogóle nie była przedmiotem badań. Prace obojga, te zachowane w zbiorach publicznych i znane $\mathrm{z}$ reprodukcji w czasopismach i katalogach przedwojennych wystaw stanowią zaledwie część dużego dorobku. Twórczość zarówno Marii Dunin, jak i Zygmunta Dunina w dużej mierze oparta na czarnym humorze i groteskowym ujęciu, zdradza upodobanie do czerni jako podstawowego środka ekspresji. „Pasją nie dająca się utrzymać na wodzy uderzaja drzeworyty Duninówny. Artystce tej nigdy nie dość jest czerni, którą kasuje swymi dłutkami z najskwapliwszym skapstwem. Wydaje się, że artystka pragnęłaby wszystko, co chce powiedzieć -

1 To umiłowanie czerni musiało być charakterystyczne, skoro po latach kolega artystki z warszawskiej Akademii Sztuk Pięknych, tak ją zapamiętał: „Któż tam był jeszcze? [...] czarna jak smoła Podolanka Maria Duninówna, wycinająca swe również czarne drzeworyty" (W. Bartoszewicz, Buda na Powiślu, Warszawa 1966, s. 112). 
powiedzieć czernią tylko. Czerń jest dla niej jakby jakąś bryłą bazaltu czy norweskiego granitu. Zwięzłymi uderzeniami dłutek wyłupuje tylko niezbędne białe akcenty dla wyobrażenia kształtu. Panuje też w jej rycinach coś posępnego jak jesienny mrok przygniatający prowincjonalne miasteczko. Czerń drzeworytów Duninówny zawisa ponuro nad widzem i nawet jej motyw sycylijski nie jest wolny od jakiegoś mroku"2 - pisał Tadeusz Cieślewski, kolega artystki z grupy Ryt.

W podobnym tonie krytycy wyrażali się o pracach Zygmunta Dunina, dostrzegając w nich ponurość, posępność, ale przede wszystkim brzydotę portretowanych typów charakterystycznych: „,...] Gwałtownymi rzutami tuszu, namiętnym ciosem dłutka drzeworytniczego wydobywa Dunin wielkie płaszczyzny czarno-białe, układające się w zdeformowany kształt ludzki. To jest więcej niż karykatura [...] To jest spotwornienie rzeczywistości, monstrum, które wykiełkowało na niej jak bakteria na pożywce. Przerost szpetoty, dławiąca inflacja ohydy, makabryczność zwyrodnienia"3.

Czarny humor, chociaż niejednakowo dosadny cechuje prace obojga. Zdecydowanie bardziej radykalny w sposobie ujęcia tematu i niewahający się przed daleko idąca deformacją był Zygmunt Dunin. Jego siostra we wczesnym okresie twórczości przedkładała pierwiastek dekoracyjny i intrygującą narrację nad deformację, ale od końca lat 20., kiedy ukształtował się dojrzały styl artystki, najważniejszym środkiem wyrazu w jej drzeworytach stała się czerń - „czerń użyta jako aktywny kolor”.

Oboje urodzeni w Kamieńcu Podolskim5: Maria 5 maja 1899 roku, Zygmunt osiem lat później, również 5 maja. Rodzeństwo mieszkało z rodzicami ${ }^{6}$ w rodzinnym mieście co najmniej do 1917 r. $^{7}$ Warszawa, mimo że była odległym punktem na mapie, stała się na kilka lat miejscem ich życia

2 T. Cieślewski syn, Siedem artystek na wystawie Rytu, „Pani Domu” 1936, nr 2, s. 25-26.

3 S.P.O. [S. Podhorska-Okołów], Zygmunt i Maria Dunin, „Bluszcz” 1936, nr 39, s. 12-13.

4 W. J. Goryńska, Contemporary wood-engraving in Poland, "The Print Collector's Quarterly" 1935, vol. 22, no 4, p. 344 (tłum. autorki).

5 Obecnie miasto w południowo-zachodniej Ukrainie, siedziba obwodu kamienieckiego.

6 Karolem i Wiktoria de domo Rakowską. Informacja na podstawie Albumu studentów Akademii Sztuk Pięknych w Warszawie, Zbiory Specjalne IS PAN, nr inw. 81 / I, k. 296.

7 W Kamieńcu Podolskim Maria Dunin ukończyła rosyjskie Mariańskie Gimnazjum Żeńskie. 
i rozwoju artystycznego. W latach 1917-1919 Maria pobierała prywatne lekcje rysunku u malarza Kazimierza Lasockiego, następnie zapisała się do warszawskiej Szkoły Sztuk Pięknych. W maju 1920 r. wróciła na wakacje do rodziny na Podole, a już w lipcu tego roku, jak relacjonowała: „zmuszona byłam uciekać z rodziną do Polski przed najazdem bolszewickim [...] w październiku 1920 r. zamieszkawszy w Milanówku pod Warszawą wstapiłam do szkoły malarskiej prof. Konrada Krzyżanowskiego, dokąd uczęszczałam do czerwca roku 1922 [...]"8. Regularne studia w warszawskiej Szkole Sztuk Pięknych Duninówna odbyła dopiero w latach 1923-19299. Uczęszczała do pracowni Tadeusza Pruszkowskiego i Władysława Skoczylasa, nauczycielami jej byli także Wojciech Jastrzębowski, Edward Trojanowski i Ludwik Gardowski. Od początku studiów borykała się z trudną sytuacją materialną - rodzice, którzy zostali w Rosji, przesyłali niewielkie sumy pieniężne, a ona utrzymywała jeszcze dwóch młodszych braci, wówczas uczniów szkoły średniej. Już w trakcie nauki młoda adeptka sztuki otrzymała wiele nagród ${ }^{10}$, wszystkie semestry z grafiki artystycznej ukończyła z ocenami bardzo dobrymi; jako studentka wystawiała swoje prace. Składane podania o stypendium na dalszą naukę i prośby o zwolnienie z opłat szkolnych były rozpatrywane pozytywnie; Duninówna wspominała o „ciagłych zabiegach o dorywcza pracę zarobkową” i trudnych warunkach mieszkaniowych (wynajęty pokój ${ }^{11}$ ), które uniemożliwiały jej pracę twórczą. Ukończyła studia w 1929 roku jako graficzka.

Zygmunt Dunin zapisał się do warszawskiej Szkoły Sztuk Pięknych od II semestru roku akademickiego 1926/1927 (1 kwietnia 1927); uczęszczał do pracowni prof. Karola Tichego, Miłosza Kotarbińskiego, Leonarda Pękalskiego i Felicjana Kowarskiego. Immatrykulowany 23 lutego 1928 roku po wcześniejszym zdaniu, w tym samym dniu, egzaminu uzupełniaja-

8 Życiorys M. Duninówny, Archiwum warszawskiej ASP: zespół akt studenckich sprzed września 1939 r., teka nr 159.

9 Przyjęta 11 marca 1923 r.

10 Nagrody i wyróżnienia za grafiki: dwanaście odznaczeń i nagrody pieniężne, niemal wszystkie z grafiki warsztatowej, jedno z malarstwa dekoracyjnego u prof. E. Trojanowskiego (adnotacje w Albumie studentów..., op.cit.).

${ }^{11}$ W willi - pensjonacie w Milanówku. 
cego $^{12}$. W roku 1930-1932 pozostawał na urlopie (chorował na gruźlicę $e^{13}$ ), następnie został wypisany z albumu słuchaczy wolnych. W Warszawie nie mieszkał na stałe, lecz bywa $1^{14}$, nadsyłał prace na wystawy (Salony IPS) ${ }^{15}$, brał też udział w I Międzynarodowej Wystawie Drzeworytów ${ }^{16}$ w 1933 roku zorganizowanej z inicjatywy Władysława Skoczylasa. Zgłosił cztery prace: Piekarze, Gitara, Owocobranie i Fikusy, z czego dwie pierwsze zostały zakwalifikowane i wystawione. Był współpracownikiem redakcji ilustrowanego miesięcznika „Naokoło Świata”. Od 1934 roku artysta przynajmniej czasowo mieszkał w Lodzi $^{17}$, tam też wystawił w lutym 1934 roku swoje rysunki w kawiarni IPS. W 1936 roku odbyła się w warszawskiej Zachęcie wspólna wystawa ${ }^{18}$ Marii i Zygmunta Duninów. Graficzka wystawiła siedemdziesiąt jeden drzeworytów (czarno-białych, barwnych i kolorowanych akwarela) - stanowiły one przegląd dotychczasowego jej dorobku od czasów studenckich po prace najnowsze. Zygmunt Dunin zaprezentował kilkadziesiąt rysunków tuszem ${ }^{19}$, drzeworyty czarno-białe (Mnisøka, Fikusy,

12 Otrzymał świadectwo wydane przez Państwowe Gimnazjum im. Tadeusza Rejtana w Warszawie.

13 Przytaczam za: M. Grońska, Nowoczesny dræeworyt polski, Wrocław 1971, która z kolei opierała się na relacji ustnej grafika Aleksandra Sołtana, zob. s. 217 cytowanej pracy. W zbiorach specjalnych IS PAN zachowało się podanie Marii Duninówny do zarządu ZPAG z prośbą o pomoc w sfinansowaniu sanatorium dla brata.

14 Podpisana przez niego lista obecności na zebraniu artystów wystawców Salonu Zimowego IPS w dniu 20.01.1932 r. w Zbiorach Specjalnych IS PAN, Salon IPS 1931-1932, k. 391).

15 Jako adres do odesłania prac i Zygmunt i Maria podawali w tym czasie (1932 rok) magistrat w Kamieńcu Litewskim.

${ }_{16}$ Maria Dunin zaprezentowała na tej wystawie cztery swoje drzeworyty: Żydzi, Paniusie, Mieszrzanie, Rabini.

17 Dwa listy Z. Dunina do Instytutu Propagandy Sztuki w Warszawie z prośbą o udzielenie sali na wystawę rysunków i drzeworytów w oddziale Instytutu w Lodzi. Zbiory Specjalne IS PAN, Materiały IPS Lódź, korespondencja, k. 99; z dn. 4 maja 1935 r.; k. 100. Tam również dwa rysunki Dunina wykonane czarnym tuszem - jeden dołączony do listu artysty do IPS z prośbą o możliwość zorganizowania wystawy w salonie IPS w Lodzi, drugi zdobiący zaproszenie na wystawę.

18 Kolekcje prac Marii Dunin, Zygmunta Dunina, Przewodnik po wystawie Towarzystwa Zachęty Sztuk Pięknych, nr 115, Warszawa, Towarzystwo Zachęty Sztuk Pięknych, 1936.

19 Lowca mikrobóm, Koń, W oknie, Poczekealnia, Sjesta, Starzec, Driewica, Pianista, Panie, Matka, Radca, Żebrak, Opuszrzony, Kuchary, Chtop, Łyk, Czynownik, Stójkony, Panna, Biurokracy, Typ Fredrowski, Bos\%, Kopacze, Sklep, Rozmowa, Żyd na rynku, Rabin i uczeń, Cadyk, Garbus, Chasy- 
Gitara, Żyd z. kozq, Piekarze, Kucharæ, Owocobranie, Weronika, Ślepa, Darcie pierza, Osiot, Krówka) oraz linoryt barwny Gtowa.

Maria Dunin po ukończeniu studiów była nadal bardzo aktywna, związana $z$ warszawskim środowiskiem artystycznym jako członkini Rytu i Związku Polskich Artystów Grafików ${ }^{20}$, choć tak jak Zygmunt nie mieszkała na stałe w Warszawie. Intensywnie tworzyła, prace wysyłała na konkursy, wystawiała nieporównanie częściej niż brat. Brała udział niemal w każdej wystawie stowarzyszenia Ryt, w Salonach IPS, w znaczących wystawach krajowych i zagranicznych, wystawach twórczości kobiet ${ }^{21}$, tematycznych $^{22}$ i przeglądowych ${ }^{23}$. Przekazywała także swoje drzeworyty na subskrypcje organizowane przez czasopisma ${ }^{24}$. Już jako młoda artystka prezentowała swe prace razem z Wiktorią Goryńską w Londynie ${ }^{25}$; z innych ważniejszych wystaw zagranicznych, w których brała udział, należy wymienić wystawę współczesnej grafiki polskiej w 1930 r. w Tokio i Osace, II Międzynarodową Wystawę Litografii i Drzeworytu w Chicago (z tego samego roku) i wystawe polskiej grafiki w Londynie ${ }^{26}$ z 1931 r. W 1933 roku Duninówna uczestniczyła w wystawach grafii polskiej w Sztokholmie, Montevideo, Lyonie, Chicago (wystawa Stulecie postępu), w 1935 r. w Madrycie; w 1936 w wystawie polskiej grafiki i tkanin w londyńskim Victoria\&Albert Museum, w 1938 r. w prezentacji współczesnej grafiki polskiej

d₹i, Szewc, Sad, U zegarmistrza, Driad, Baba, Tancerka, Driad z. kwiatkiem, Marianna, Lektura, Pisarz, Chemik, Negus, Pop.

20 Zygmunt Dunin również należał do ZPAG.

21 W 1934 r. sekcja sztuki kobiecego klubu Lyceum we Florencji zorganizowała wystawę Maria Vergine Vista Della Donna (Madonna widziana przę kobiete). Rok później, dzięki wcześniej nawiązanym kontaktom, inicjatywie Wiktorii Goryńskiej przy współpracy z TOSSPO oraz za pośrednictwem Samuela Tyszkiewicza (i poprzedzona jego prelekcją) odbyła się we Florencji wystawa prac polskich graficzek. W obu Maria Dunin brała udział.

22 M.in. Międzynarodowa mystawa sұtuki religijnej w Padwie (1931), Sport w sqtuce w Warszawie (1936), Wystawa grafiki myśliwskiej w Poznaniu (1938), Święci polscy w sætuce w Warszawie (1939).

23 Wystawa grafików polskich w bydgoskim Muzeum Miejskim (1931).

24 Uczestniczyła w siedmiu organizowanych przez warszawskie „ABC Literacko-Artystyczne” i „Prosto z Mostu” oraz przez poznańskie pismo Tęcza”, które w 1936 r. ogłosiło subskrypcję drzeworytów o tematyce religijnej.

25 Wystawa w 1929 roku w lokalu londyńskiego stowarzyszenia Faculty of Arts.

2660 nadesłanych prac przekazano następnie w darze British Museum. 
w Ottawie. Ostatnia wystawa, w której brała udział, to Międzynarodowa Wystawa w Nowym Jorku Świat Jutra w 1939 r.

Artystka tak jak jej brat zmieniała miejsca swego pobytu, jak wynika to m.in. z dokumentacji wystaw Instytutu Propagandy Sztuki w Zbiorach Specjalnych IS PAN i katalogów wystaw ${ }^{27}$. Od 1935 r. mieszkała najpierw w Sierpcu, później w Płońsku ${ }^{28}$. Środowisko tych małych miasteczek oddziałało na twórczość Duninówny - w jej drzeworytach z tego czasu pojawiają się widoki drewnianej zabudowy uliczek, malowniczych podwórek i zaułków, maleńkich sklepików i zakładów usługowych w parterze domów. Trudno dziś określić przyczyny tej stosunkowo częstej zmiany miejsc, zwłaszcza że bardzo niewiele wiadomo o życiu prywatnym tej graficzki i jej brata. Na podstawie pewnych wskazówek znalezionych m.in. w zbiorach specjalnych IS PAN można snuć domysły, stawiać hipotezy i bardzo niewiele ustalić ponad wszelką wątpliwość. Maria Dunin jako miejsce zwrotu prac po wystawie najczęściej podawała warszawski adres i nazwisko Piotrowskiego (przyszłego męża?) lub Piotrowskiej (jego matki? siostry?). Prace Duninówny odbierała także nieznana z pełnego brzmienia imienia W. Ostrowska i Wiktoria Goryńska, koleżanka z Rytu. Jeśli któreś z rodzeństwa przebywało w Warszawie, to odbierało prace drugiego $^{29}$. Ich przeprowadzki być może podyktowane były koniecznością zarobkowania, być może w kolejnych miastach, do których przenosili się Maria i Zygmunt, mieszkali ich krewni. Maria Duninówna wyszła za mąż w 1938 roku, jednak żadna ze znanych mi prac nie jest sygnowana podwójnym lub mężowskim nazwiskiem (zawsze Duninówna lub Dunin). W katalogach wystaw od 1938 r. artystka figuruje natomiast jako Maria Dunin-Piotrowska. Ostatnim bodajże śladem jej przedwojennej twórczości

27 W 1930 roku jako miejsce kierowania korespondencji podała: „poczta Czernawczyce, pow. Brześć n/Bugiem”, a jako odbiorcę dzieł wskazała Wiktorię Goryńską (zgłoszenie na Salon Listopadowy IPS 1930, Zbiory Specjalne IS PAN, k. 33). W 1932 i 1934 roku (katalog wystawy drzeworytów w Lodzi, styczeń 1934) jako miejsce pobytu (lub miejsce, pod które należy odesłać prace) podała Kamieniec Litewski; taki sam adres podał jej brat.

28 W roku 1935 i 1936 mieszkała w Sierpcu, następnie w Płońsku; jej brat na zmianę w Warszawie i Lodzi (w ciagu dwóch lat mieszkał pod dwoma łódzkimi adresami).

29. Wzajemne upoważnienia do odbioru prac Marii Dunin i Zygmunta Dunina pisane tym samym zielonym atramentem zachowane w Zbiorach Specjalnych IPS. 
są drzeworyty z 1938 r. wysłane na wystawę do Nowego Jorku, pt. Nike i Thukacze kamieni ${ }^{30}$.

Artystka we wczesnym okresie twórczości wypowiadała się, obok drzeworytu także w technikach miedziorytu i suchej igły (Jarmark, Przekupnie, Śmier'́ w gościnie, późniejsze już ilustracje do The Krakus and the Dragon $\left.{ }^{31}\right)$. Prace te cechuje dobry, choć oschły rysunek i dokładne odzwierciedlenie nie tylko rysów twarzy, ale też mimiki, gestów, wieku - wszelkich jednostkowych cech danej postaci. Od najwcześniejszych prac w kręgu zainteresowań Duninówny był przede wszystkim człowiek, a nie architektura (jak w twórczości wielu polskich graficzek dwudziestolecia międzywojennego), choć niejednokrotnie jest ona tłem dla narracji. Ten odmienny sposób myślenia, postrzegania i określania świata przez pryzmat własnej wrażliwości widoczny już jest w jednej ze studenckich prac na zadany temat ${ }^{32}$. Zapewne jest to Prometeusz, kompozycja wykonywana przez studentów grafiki w warszawskiej szkole około 1925 roku. Rozpiętość epizodów z życia mitycznego bohatera i konwencji ich ujęcia w pracach studenckich jest znaczna, zadziwia różnorodność pomysłów młodych artystów ${ }^{33}$. Duninówna w ujęciu tematu była na swój sposób jeszcze bardziej radykalna, bo „sprowadziła” herosa do współczesnych sobie czasów, do zwykłych ludzi grających w karty w małomiasteczkowej karczmie, zadziwionych pojawieniem się wśród nich muskularnego, gigantycznego całkowicie nagiego młodzieńca z pochodnią w jednej dłoni i zapałką w drugiej.

Drzeworyt jako własną technikę wybrała Duninówna od początku drogi twórczej; po obowiązkowym zapoznaniu się z warsztatem innych technik

\footnotetext{
30 Wystawione w Pawilonie Polskim na Międzynarodowej Wystawie w Nowym Jorku w 1939 r.

31 Krakus and the Dragon: an early Polish Legend, paraphrased from the dramatic version of C. K. Norwid by Victorya Gorynska ; with 3 engravings by Marya Dunin, Frankfurt a. Main [s.n.], 1929.

32 Miedzioryt ze zbiorów Biblioteki Jagiellońskiej określony jako kompozycja alegoryczna; jedna z wielu prac studenckich przekazanych tej instytucji przez warszawską Akademię Sztuk Pięknych (tzw. dar ASP) w 1932 r.

33 Od podążających za mitem wizji męki Prometeusza - dobroczyńcy ludzkości, po Prometeusza w stylizacji góralskiej czy ujętego jako Chrystusa (prace ze zb. BJ: Mieczysława Bartodziejskiego-Dunina, Juliana Bohdanowicza, Ines Rosnerówny, Marii Sieraczyńskiej, Jadwigi Umińskiej, Alicji Kruszewskiej [McKelly], Mery Litauerówny, O. Pfefferówny).
} 
drzeworyt stał się dla artystki jedynym, ale w jakże różnorodny sposób wykorzystanym medium. Najczęściej uprawiała drzeworyt czarno-biały, choć także barwny i kolorowany. W drzeworytniczej twórczości Duninówny łatwo wyodrębnić kilka mocno zróżnicowanych faz twórczości; poszukiwała, była zmienna, niespokojna, nie wahała się porzucać dotychczasowych, wypracowanych już metod, by odnaleźć nowe możliwości, nowy wyraz w tej samej technice.

Zadebiutowała w 1925 r. drzeworytniczymi ilustracjami ${ }^{34}$ do Żymych kamieni Wacława Berenta wysoko ocenionymi przez krytykę za dostrojenie charakteru tych niewielkich winiet do treści utworu literackiego. Rok późniejsze tzw. ryciny królewskie: Król Smutny, Wesoly (Rubaszny, Sprośny), Łaskawy, Groźny, Uçony (Madry) to drzeworyty kolorowane jaskrawymi barwami zdradzające inspiracje XVI-wiecznym drzeworytem. Spłaszczenie przestrzeni, prostota cięcia, jasno określony kontur wzbogacony drobnym kreskowaniem utrzymuja charakter archaicznej prostoty dawnego drzeworytu. Prace, których akcja osadzona została w „baśniowym” średniowieczu: Turniej, Śpiaca królewna, Legenda średniowiecz̨na są w swej zagęszczonej narracji swoistym odpowiednikiem ,janosikowych” zbójnickich opowieści drzeworytniczych Skoczylasa, choć reprezentują inny, rycersko-dworski krag tematyczny. W 1927 roku Duninówna wykonała serię drzeworytów Praystowia polskie ${ }^{35}$. Jeśli temat na to pozwalał, artystka puszczała wodze fantazji, powołując do życia fantastyczne stworzenia - w Proystowiach (rycinach Strach ma wielkie ocąy oraz Sen mara - Bóg wiara ${ }^{36}$ ) wykreowała wywodzące się jakby z sennych wizji przedziwne stwory, które maja także potencjał komiczny. Symetria, płaskość, symultaniczność scen oraz duży nacisk na dekoracyjność (bogactwo ornamentu i deseni, zróżnicowany sposób prowadzenia narzędzia) to cechy,

34 Reprodukowane w: „Pologne Litteraire”, dod. do „Wiadomości Literackich” 1930, nr 46, s. 2.

35 Gdzie diabet nie možz tam babe pośle, Bez. pracy nie ma kołacsy, Strach ma wielkie oczy, Śmierí $i$ żona od Boga przeznaczona, Gość w dom - Bóg w dom, Sen mara - Bóg wiara.

36 Oprócz kotów, gryfów, nietoperzy, lisów, stworzeń przywołujących na myśl chimery, wytropić można w tych kompozycjach uskrzydlone węże, ludzkie postacie z głowami zwierząt, dwugłowe i sześciorękie postacie. Duninówna czerpie pełnymi garściami z dziedzictwa Zachodu i Wschodu - odwołuje się do mitologii greckiej, sztuki Egiptu, Indii, także do bestiariusza średniowiecznego, ale motywy te przetwarza po swojemu, tworząc nowe wersje znanego już zasobu. 
które łączą te prace artystki z pracami jej koleżanek, także uczennic Skoczylasa (cykl B. Krasnodębskiej-Gardowskiej Objawienie św. Jana Teologa z 1925 r. i z tego samego roku J. Konarskiej cykl Świeci patroni).

Zofia Ameisenowa zauważyła, że choć po rycinach do Psalmów Dawidomych Kochanowskiego można poznać, że artystka była uczennicą Skoczylasa, „to jednak obok tej zależności przebłyskuje już wyraźnie silna indywidualność artystki. Widać ją w szeroko asymetrycznie rozplanowanej kompozycji, w energicznie ciętej, mocno czarnej, grubej kresce, w upodobaniu do bogatej wzorzystości szat, wreszcie, i to przede wszystkim, w żyłce narracyjnej tej Goethowskiej die Lust Fabulieren, która skłoniła potem artystkę do ilustrowania przysłów" "37. W Psalmach z 1928 r. artystka oparła koncepcję na symultanicznym ukazaniu kilku różnych motywów lub wątków. Poszczególne kompozycje cechuje płaskość, a statyczne układy postaci w zastygłych pozach i patetycznych gestach ożywia nagromadzenie motywów i urozmaicenie tła, odmiennego dla każdego z ukazanych wątków. W drzeworytach tych artystka działa głównie ornamentem i drobnym, bogatym deseniem ubrań postaci, zróżnicowanym wzorem poszczególnych partii skrzydeł anielskich czy smoczego grzbietu, bogatą fakturą określa korony drzew. Artystka wypowiada się poprzez kreskowanie równoległe i krzyżowo przecinające się, a we fragmentach tła, tak jak w Prazystowiach stosuje archaizujące groszkowanie. Te prace podlegaja jeszcze silnemu wpływowi Skoczylasa, ale mają też wiele wspólnego z podejściem „Rytowniczek” do ornamentu i dekorowania strojów postaci. Cechą charakterystyczną tych drzeworytów jest horror vacui i zróżnicowanie faktury - artystka chcąc za wszelką cenę uniknąć monotonii tła żłobi, nakłuwa, drąży, wyłupuje każdy centymetr klocka drzeworytniczego w formy gwiazdek, trójliści, punktów, cętek, drobnych kresek, elementów przypominających litery U i V. Intrygujące sa monumentalne postacie aniołów-rycerzy na jednej z rycin ${ }^{38}$ : w czarnych zbrojach, z tarczą i wzniesionym mieczem. Z niezwykła pomysłowością tworzy artystka hybrydy - bohaterów cyklu alegorii Cžtery ṡymioły (1928).

37 Z. Ameisenowa, Rqut oka na wspótczesna grafike polskeq. Katalog wystawy w BJ, Kraków 1939, s. 24 (wystawa, do której przygotowano katalog, nie odbyła się z powodu wybuchu II wojny światowej).

38 Psalm 91: Qut habitat in adiutorio Altissimi. 
Przetwarza znane motywy: orła, gryfa czy salamandry i łączy je z ludzką postacia. Obleka je w geometryzujące, kryształkowo rozdrobnione i rytmiczne formy art décowskie. Jednolicie barwne $\mathrm{tło}^{39}$ skontrastowane z fantastycznymi ludzko-zwierzęcymi postaciami, których ciała zdobione sa gęstym, dekoracyjnym deseniem, podnosi walory tych kompozycji.

Po 1930 r. w twórczości drzeworytniczej Duninówny nastapiły zasadnicze zmiany - zaprzestała ona drążenia w czerni klocka bogatych, drobnych i zróżnicowanych deseni, odrzuciła natłok i rozdrobnienie form, porzuciła kreskę na rzecz dużych płaszczyzn czerni i bieli, stawiając od tej pory na lapidarność techniki i kompozycji. Obserwacja, duże poczucie humoru podszyte upodobaniem do makabreski, umiejętność ujawnienia zaskakujących aspektów i niuansów, wydawałoby się, banalnych sytuacji i zjawisk to cechy, które Maria Dunin, jako dojrzała artystka, świadoma swych możliwości i kierunku poszukiwań uzewnętrzniała poprzez drzeworyty. Od 1930 roku jej żywiołem był niepodzielnie drzeworyt, a w drzeworycie największą wartość miała czerń (zarówno jako płaszczyzna, jak i kontur). W zakresie tematyki artystka zwróciła się ku współczesnym scenom rodzajowym, obserwowanym na ulicy, w zoo czy w cyrku. Krytycy od razu dostrzegli tę zmianę z początku lat 30., sygnalizując ja słowami: „Duninówna zrzuciła z siebie cudzą skórę i od razu zabłysnęła prawdziwym talentem. Zakres tematów i styl techniczny jej Spržedasy syren i Żydów bardziej odpowiada temperamentowi rasowemu artystki, niż przysłowia ludowe i 'szkoła Skoczylasa'. Duninówna zrzuciła maskę obcości i znalazła się na właściwym gruncie”"40 oraz: „Maria Dunin w dwóch swoich drzeworytach weszła jakby na szersza droge - bez dawnego przeładowania zdobniczego - a z zaletami mocy i bogactwa walorów"41.

39 Dla każdego żywiołu inne: liliowe dla powietrza, czerwone dla ognia, ugrowe dla wody; brak planszy z żywiołem ziemi. W katalogu - albumie Sz̧uka wsžedzie. Akademia Sžtuk Pieknych w Warszanie 1904-1944, koncepcja M. Sitkowska, red. naukowa J. Gola, M. Sitkowska, A. Szewczyk (wyd. Akademia Sztuk Pięknych w Warszawie, Warszawa 2012) zamieszczona jest reprodukcja drzeworytu Duninówny określonego jako herb Warszawy - bardziej prawdopodobne jednak, że jest to jeden z żywiołów.

40 T. Cieślewski, Salon Listopadowy IPS, „Jutro” 1930, z dn. 14 XII, s. 98.

41 J. Kleczyński, Z Salonu Listopadowego u Baryczkón, „Kurier Warszawski” 28 XII 1930, nr 353 (wycinek prasowy Zbiory Specjalne IS PAN). 
Jej realistyczny w formie drzeworyt Wenecja - sprzedawca syren (1930) jest jedna z pierwszych kompozycji odzwierciedlających nowe oblicze artystki i śmiały zwrot w kierunku groteski, której zapowiedzi zauważalne były do tej pory jedynie w poszczególnych scenkach współtworzących kompozycję Praystón ${ }^{42}$. Praca przedstawiająca banalną z pozoru scenę handlu rybami zaskakuje błyskiem szczególnego humoru Duninówny, gdy pomiędzy różnymi gatunkami ryb i owoców morza wyłożonymi na straganie oko widza dostrzeże syreny - jedną zwisająca za włosy, drugą prezentowaną na ladzie, zachwalana przez dobrotliwie uśmiechniętego staruszka sprzedawcę. $\mathrm{Na}$ poły zgrzytliwe, na poły komiczne zestawienie (postaci syren o ludzkim powyżej pasa ciele, kobiecych twarzach i długich włosach jako towaru na sprzedaż w sąsiedztwie ryb) będzie wyróżnikiem późniejszej twórczości artystki. Tego typu poczucie humoru wyróżnia Duninównę nie tylko spośród innych członkiń Rytu, ale graficzek międzywojnia w ogóle.

Charakterystyczna dla tej artystki wnikliwa obserwacja ludzi i zwierząt przełożyła się na syntetyczne, bardzo wyraziste wizerunki drzeworytnicze. Artystka „chwyta” typy charakterystyczne i przedstawia je w krzywym zwierciadle, utrwala scenki, wydarzenia pozornie zwyczajne: handlarzy i zwierzęta na jarmarku, ludzi w codziennych, zwykłych - niezwykłych sytuacjach, ma dar dostrzegania i ukazywania groteskowo-komicznego potencjału danej sytuacji. Taki jest drzeworyt Maski [gazowe] z 1931 r. Na tle zabudowań niewielkiego miasteczka ${ }^{43}$ artystka portretuje ludzi w maskach gazowych. Inspiracją do podjęcia takiego wątku były zapewne organizowane w latach 30 . szkolenia na wypadek wojny gazowej ${ }^{44}$ i organizowane

\footnotetext{
42 Jako całość poszczególne plansze traca jednak te komiczno-groteskowe akcenty, przytłacza je dekoracyjność kompozycji i podporządkowanie poszczególnych motywów wymowie całości. Stefania Podhorska - Okołów o jednej z planszy cyklu pt. Śmierí i żona od Boga przęnaczona zauważyła: „to bliskie sąsiedztwo żony i Kostuchy budzi jaką́s makabryczną wesołość” S.P.O. [S. Podhorska-Okołów], Zygmunt i Maria Dunin, „Bluszcz” 1936, nr 39, s. 13 .

43 Kamieniec Litewski, Sierpc, Płońsk (we wszystkich była cerkiew, której kopuły widoczne w tle pracy) lub jakiekolwiek małe miasteczko.

44 Kursy obrony przeciwgazowej prowadzone były w Warszawie w latach 30. W stolicy zorganizowano Koło Pań Obrony Przeciwgazowej, które miało za zadanie przygotowania kobiet, w razie wojny gazowej do odpowiednich zachowań. („Bluszcz” 1931, nr 45, s. 14.) Artykuł z „ABC Literacko-Artystycznego” (1933, nr 45, s. 4) donosił o konieczności przy-
} 
przemarsze w maskach gazowych, które na artystkę tak wyczuloną na humorystyczne akcenty w budzących nawet grozę i pełnych powagi okolicznościach mogły podziałać inspirująco. W drzeworycie Duninówny dwie postacie na pierwszym planie w hełmach na głowach moga być po prostu żołnierzami, jednak postacie w tle to cywile, którym maska na głowie przydaje komiczno-makabrycznego charakteru. Artystka ujęła ich tak, że bardziej przypominaja egzotyczne zwierzęta o wydłużonych pyskach i z okragłymi „ślepymi” szkłami zamiast oczu. W tej pracy najbardziej zbliża się sposobu opisu świata w rysunkach swego brata Zygmunta. Wyczuwa się niepokój i napięcie w tej kompozycji, ale też nieme wyczekiwanie, bo postacie swą postawa, sylwetką sprawiają wrażenie, że zastygły w bezruchu w upiornej pantomimie. W tej kompozycji duża część klocka drzeworytniczego nie została draśnięta nawet dłutkiem - na odbitce rozpościera się jako czerń nieba podkreślająca nastrój niepokoju.

Dorobek artystki zachował się, jak już wspomniano, tylko częściowo. Niezwykle trudne byłoby określenie, jaka jest to część, nawet na podstawie przedwojennych katalogów wystaw i wzmianek w recenzjach, choć tytuły - może nawet połowy dorobku graficznego - znane sa jedynie z takich źródeł. Groteskowy charakter miał zapewne recenzowany przez Mieczysława Wallisa drzeworyt jeszcze z czasów studiów artystki Na tamtym swiecie (1925): ,[...] oryginalny w pomyśle drzeworyt [...] ze szkieletami ludzi, ptaków, ryb, jakby wycinek rzeczywistości prześwietlony promieniami Roentgena." ${ }^{45}$ Drzeworyt Paniusiee (przed 1936 r.) być może ujawniał umiejętność Duninówny dostrzegania komizmu w banalnych sytuacjach, jej zmysł

sposobienia się do obrony przeciwgazowej; w tonie ironicznym autor pisał o wprowadzeniu kursów i szkoleń prowadzonych przez inżynierki i chemiczki dotyczących obchodzenia się maskami gazowymi. Motyw maski gazowej prowokował grafików do ujęć humorystycznych lub groteskowych, zabarwionych groza (np. rysunki satyryczne w czasopiśmie „Cyrulik Warszawski”, 1932)

45 M. Wallis, Maria i Zygmunt Duninowie, „Wiadomości Literackie” 1936, nr 43, s. 5. Wydaje się, że tę kompozycję miała na myśli Goryńska, charakteryzując ją jako „Rybak - sæ̌kielet, wczesna praca, niezwykle rzadka” (W. J. Goryńska, Contemporary wood-engraving in Poland, op.cit.) Częstotliwość przedstawiania szkieletu ludzkiego w sposób humorystyczny w pracach obojga wskazuje także na wspólne upodobanie do tego właśnie motywu.

46 O pracy tej pisał Tadeusz Seweryn: ,pełna nowego, indywidualnego wyrazu w grotesce zatytułowanej Paniusie” (T. Seweryn, Dræeworyt wspótcresny, „Sztuki Piękne” 1933, s. 454). 
wyczulenia na śmieszność i „pozę” w zachowaniach ludzi i ich wzajemnych relacjach.

W postawie artystycznej i oglądzie świata Marii Duninówny i jej młodszego brata Zygmunta odnajdziemy wspólny rys, choć w drzeworytach Marii ponure aspekty rzeczywistości czy brzydota fizjonomii nie sa tak ostentacyjnie wydobywane na światło dzienne jak w pracach Zygmunta Dunina. Rodzeństwo podobnie postrzegało rzeczywistość, z tym że Zygmunt w swym wyczuleniu na turpistyczne elementy, karykaturalnym zacięciu $^{47}$ i radykalizmie ujęcia szedł znacznie dalej. Silną deformację postaci, świadome szukanie brzydoty i bezlitosność w jej uwypuklaniu podkreślali w pracach tego grafika i rysownika Nela Samotyhowa ${ }^{48}$, Mieczysław Wallis ${ }^{49}$ i Stefania Podhorska-Okołów ${ }^{50}$. Ta ostatnia jednak zauważyła zupełnie odmienne podejście artysty wobec wizerunków zwierząt: „rysunki zwierząt

47 Artysta wykonywał satyryczne ilustracje do „Cyrulika Warszawskiego” (1932)

48 „[...].) Zygmunt Dunin, w dążeniu do ekspresji zużytkowujący wszelkie odmiany brzydoty: pokraczność, bestialstwo, deformację, potworność. Przesada i akcentowanie - dwie z dróg wiodących do karykatury - prowadzą tutaj do makabrycznego odczłowieczenia ludzi. Nie mniej sztuka jego urzeka, jak koszmar i pociaga wysoką klasą wykonania. [...] Żyje w nim satyryk, ktoś z gatunku Goi. Sztuka jego, ostra i silna, poszerzona i pogłębiona, mogłaby się stać biczem chłoszczącym nasze życie” (N. Samotyhowa, W'śód dzieł squtuki, „Praca Obywatelska” 1936, nr 19, s. 11).

${ }^{49},[\ldots]$ Posępny, zgryźliwy, żółciowy humor wyładowuje się w tych utworach. [...] z ponurą pasją i zawziętością zdziera z nich maski: 'Myślicie, że istoty, z którymi obcujecie, to ludzie? Przyjrzyjcie się im bliżej: to przecież orangutangi, pawiany, świnie o długich ryjach. [...] W ten sposób Dunin demonstruje nam łyków i urzędników, radców i kupców, cadyków i popów, paniusie prowincjonalne i jędze kawiarniane. Istne panopticum brzydoty fizycznej i moralnej” (M. Wallis, Wystany. Maria i Zygmunt Duninowie. Zachęta, „Wiadomości Literackie" 1936, nr 43, s. 5).

${ }^{50}$ W jeszcze bardziej dosadnych słowach („ucieleśniona obsesja brzydoty”, „pasja tropienia brzydoty") oceniła postawę Zygmunta Dunina Stefania Podhorska-Okołów, na której prace artysty wywarły piorunujące wrażenie. Warto je tu przytoczyć, bo oddaja skalę emocji odbiorcy: „W małym miasteczku [...] lęgną się grzyby zmurszałych domków i grzyby ludzkie. Zwyrodniała rasa chasydów, straszne sylwetki złożone z chałata, kaszkietu i monstrualnego nosa, kobiety rozlane jak ropuchy, senne twarze rabinów i ich uczniów, Żyd i koza - oto tematy potwornych zjaw wyzwalających się boleśnie z wyobraźni Zygmunta Dunina. [...] Oto 'bosz', niemiecki piwosz o bezmyślnej nabrzękłej twarzy pod płaskim deklem. Oto jegomość z waszecią o sprytnej i zawadiackiej gębie, oto szkielety kobiece w staromodnych sukniach i zeszłowiecznych kapeluszach obsiadły stolik [...].” (S.P.O. [S. Podhorska-Okołów], Zygmunt i Maria Dunin, op.cit., s. 12-13). 
u Dunina maja tę filuterną przekorność, na którą nigdy nie może się zdobyć wobec świata ludzi. Zwierzęta go bawią i cieszą. Na widok człowieka jego wyobraźnia wzbiera wstrętem i goryczą"51. O słuszności tej refleksji (we fragmencie dotyczącym zwierząt) może świadczyć reprodukcja wizerunku pociesznego kota wykonanego tuszem przez Dunina ${ }^{52}$. Prace rodzeństwa z motywem zwierząt (nie brakuje ich ani w drzeworytach Marii, ani w rysunkach Zygmunta) sa potwierdzeniem fascynacji obojga światem „braci mniejszych”, w którym znajdowali być może swobodę, szczerość zachowań, wolność od konwenansów i reguł obowiązujących w schematach towarzyskich relacji międzyludzkich.

Swoje rysunki satyryczne, w których czasem przekształcał ludzi w zwierzęta, Zygmunt Dunin zamieszczał w „Cyruliku Warszawskim” (1932 r.) obok czołówki polskich rysowników (m.in. Mai Berezowskiej, Ireny Kuczborskiej, Jerzego Zaruby, Feliksa Topolskiego, Mieczysława Piotrowskiego ${ }^{53}$ ). Te niewielkie rysunki ${ }^{54}$ : Zwariowany prelegent, Meloman, Zwachali sie, Primavera, Nieberpieczny ptaszek, Rozmowa zasadnicza wykonane tuszem to zaledwie próbka stylu Dunina, mogąca dać jednak pewne wyobrażenie o doznaniach recenzentów porażonych stopniem jego fascynacji brzydotą. Koncepcja karykatur rysowanych przez Dunina opiera się na przesadnym wyolbrzymianiu pewnych elementów fizjonomii, ich deformacji lub upodobnieniu ludzi do zwierząt. Ten ostatni zabieg widoczny jest szczególnie w rysunku Rozmowa zasadnicza, która najwyraźniej rozgrywa się między szefem a podwładnym. Szef nakreślony grubą (dosłownie) kreską, z podłużnym nosem przekształconym w ryj i wielkimi łapami drapieżnika wyglądem przypomina dzika ze zjeżoną szczecina. Rozwarty szeroko otwór gębowy nie pozostawia wątpliwości, że krzyczy; ,słuchaczem” jest okularnik wątłej postury, ze spuszczona, przesadnie dużą głowa, obdarzony wydatnym, kulistym nosem. Spogląda on z obawą na stojącego nad nim szefa. Komizm sytuacji, nawet

\footnotetext{
51 Ibidem, s. 13.

52 Zamieszczona obok recenzji M. Wallisa Wystawy. Maria i Zygmunt Duninowie, s. 5.

53 Mieczysław Tadeusz Piotrowski (1910-1977), absolwent Wyższej Szkoły Dziennikarskiej w Warszawie (1931) i warszawskiej ASP (1935). Zbieżność nazwisk z mężem Marii Dunin jest raczej przypadkowa, o czym mogą świadczyć dane biograficzne.

54 Twórczość Zygmunta Dunina z niewiadomych powodów pominięto w publikacji H. Górskiej i E. Lipińskiego, Z dziejón karykatury polskiej, Warszawa 1977.
} 
jeśli miał być dla odbiorcy czytelny, został tu przygaszony sposobem charakterystyki postaci. W rysunku Zwachali się kobieta i mężczyzna stojący w pewnej od siebie odległości stykaja się długimi, spiczastymi nosami. Ukazane z profilu oblicza raża przerysowaniem proporcji nie tylko nosów. Współczesny odbiorca $z$ takim typem deformacji postaci jest raczej oswojony $-\mathrm{w}$ niektórych ilustracjach zbliżone zabiegi stosuje chociażby Stasys Eidrigevicius. Podobnie jak w innych rysunkach także i w tym Dunin posłużył się mocnym czarnym konturem, kreskami i plamami czerni, która zaciera ostrość i detale twarzy, ubioru postaci. Czerń rysowanych sylwet występuje pozornie jako zespoły drobnych plamek, cętek, dając efekt zamazania, ale w ostatecznym oglądzie czerń zagarnia spore obszary bieli, rozlewając się po sylwetach. Kontury postaci nie są określone jednoznacznie czystą linią, a ten świadomy zabieg „brudzenia” elementów rysunku dodatkowo wzmaga ich niepokojący wyraz. Taki typ ujęcia silnie wpływa na odbiór widza - ostatecznie to w jego umyśle postać formuje się i nabiera określonych kształtów, a w tym przypadku odszyfrowywanie pewnych form staje się procesem rozciagniętym w czasie. Podsumujmy: gruby czarny kontur, wyrazista deformacja, przerysowana mimika i wyolbrzymione fragmenty ciała ${ }^{55}$ to cechy rysunków zamieszczonych w „Cyruliku”, ale przynajmniej część z nich odnosi się też do innych prac artysty. Jak wynika z recenzji, ten rodzaj deformacji, ukazywanie portretowanych już nawet nie w krzywym zwierciadle, ale jako zwyrodniałych, chorobliwych form cielesnych ${ }^{56}$ nie mieścił się $\mathrm{w}$ granicach tolerancji kilku polskich krytyków, choć trzeba przyznać rację Neli Samotyhowej, jeszcze

$55 \mathrm{Na}$ kilku rysunkach artysta rozbudował fragment między nosem a górną wargą postaci, wyolbrzymił uszy, upodobniając twarz człowieka do pyska małpy.

${ }^{56}$ Taki sposób obrazowania mógł być porównywalny z twórczością w zakresie grafiki artystów republiki weimarskiej; dość przypomnieć bezlitosną obserwację przełożoną na charakterystykę typów ludzkich (nie tylko ze środowisk marginesu) i scen przemocy w tece litografii Piekło Maxa Beckmanna (1919), wizerunki rannych, konających i rozkładajacych się trupów w tece akwafort i akwatint Wojna Otto Dixa (1924). Również inni artyści niemieccy tego czasu (Heinrich Ehmsen, Bernhard Kretzschmar, Walter Gramatte) uwypuklali w swoich grafikach brzydotę portretowanych (tu należałoby uwzględnić różne przyczyny takiego ujęcia), a szczególnie zwyrodniałe, spotworniałe formy ludzkich fizjonomii i postaci odnajdziemy w litografiach Georga Scholza. 
raz powtórzę, że „sztuka jego urzeka, jak koszmar i pociaga wysoką klasą wykonania" ${ }^{\prime 27}$.

Twórczość graficzna Zygmunta Dunina porównywana była do francuskiego ekspresjonisty Charles'a Dufresne'a ${ }^{58}$. Zachowane drzeworyty ${ }^{59}$ znacznie różnią się od karykaturalno-groteskowych ujęć znanych z „Cyrulika”. Poza tym, że artysta pozostaje w nich „wyznawcą" czerni jako środka, poprzez który potrafi wypowiedzieć się najpełniej, nie ma między rysunkami a drzeworytami wspólnego mianownika. Drzeworytniczy Autoportret z 1935 r. to wizerunek inteligenta „pod krawatem” o uważnym, refleksyjnym spojrzeniu zwróconym w kierunku widza. Intrygujący jest szkic architektoniczny w tle - po prawej stronie popiersia artysty widnieje rzut ścian budynku przeprutych otworami oraz rzut klatki schodowej z zaznaczonym kierunkiem biegu schodów. W tle, zza głowy portretowanego wyrastaja sylwety wysokich budynków. Uwage przykuwa jednak przede wszystkim faktura drzeworytu. Artysta określił twarz migotliwą tkanką bieli uzyskaną krzyżującymi się pod różnymi kątami i biegnącymi w różnych kierunkach cięciami ostrzem wielokrotnym. Przecinanie się śladów daje efekt nierównomiernej siatki bieli szczególnie zagęszczonej właśnie w partii twarzy. W drzeworycie Odpocsywajacy narciare (1935) statyczna sylweta postaci siedzącego na kamieniu mężczyzny skontrastowana została z ekspresyjnie potraktowanymi żłobinami tła - pasmami bieli z prześwitami czerni. Również w tej pracy czerń dominuje - artysta sposobem cięcia drzeworytniczego klocka ujawnia, że czerń jest dla niego wartościa prymarna, nie tylko dlatego, że wynika z własności techniki drzeworytniczej (biel z czerni klocka wydobywa ślad narzędzia). Demonstracja bęrobotnych, drzeworyt z 1935 r. oparty jest na koncepcji przenikania się ${ }^{60}$ sylwet i motywów. W tej wypowiedzi zaangażowanej społecznie artysta ukazuje świat sytych i głodnych. Witrynę piekarni z wyłożonym pieczywem obserwowana przez policjan-

57 N. Samotyhowa, op.cit., s. 11.

58 T. Seweryn, Dræ̧eworyt wspótczesny, „Sztuki Piękne” 1933, s. 454.

59 Jedyne znane mi grafiki autorstwa Zygmunta Dunina znajdują się w zbiorach Ossolineum.

${ }^{60}$ Z takim zabiegiem przenikania się sylwet i obiektów mamy do czynienia w akwafortach członka I Grupy Krakowskiej, Leopolda Lewickiego, ale przy zastosowaniu zupełnie innych środków i uzyskaniu efektów wynikających z technik wklęsłodruku. 
tów kontrastuje z tłumem ubogich ludzi, których reprezentuje tytułowy bosonogi bezrobotny, z dłońmi wielkimi jak bochny opuszczonymi w geście bezradności. W tle kobieta, dziecko, a jeszcze dalej tłum postaci ukazanych jako bezimienne sylwetki.

Problematyka społeczna nie zdominowała twórczości graficznej Duninówny, jednak kilka drzeworytów świadczy o jej zainteresowaniu codziennym życiem zwykłych, niezamożnych ludzi. W drzeworytach $W$ iæ̧bie, Powód乏́, Przedmieście, Żydzi w miastečku, Krawcowa - kompozycjach na pozór statycznych artystka osiagnęła dużą ekspresję umiejętną grą dopełniających się płaszczyzn czerni i bieli, w nieznacznym tylko stopniu wzbogaconych faktura. Duninówna zwracała uwagę na uniwersalny wymiar wspólnoty ludzkich doświadczeń wobec tragedii, uwznioślała macierzyństwo ${ }^{61}$ i codzienną znojną pracę. Powódź ze zmonumentalizowaną i zastygła w bólu grupą opłakująca zmarłe dziecko, Mieczysław Wallis określił jako „lapidarną w ujęciu, szlachetnie ludzką, wzruszającą"62.

Zapewne na przełomie 1930 i 1931 roku artystka była w Wenecji, być może w tym samym czasie lub kilka lat później na Sycylii. Drzeworyty barwne Wenecja - karnawat (1931), Selinunte (1935), Taormina (1936) i Palermo inspirowane sceną rodzajową i pejzażem odzwierciedlają inną wrażliwość tej graficzki na barwę niż jej koleżanek z grupy Ryt. Duninówna w tych pracach nie rezygnuje z czerni, która nadal gra podstawowa rolę w określeniu form. W pejzażach sycylijskich dopełnieniem czerni i niewielkich płaszczyzn bieli są delikatne barwy, jakby spłowiałe, wyblakłe od palącego słońca, kryjące znaczne fragmenty kompozycji - zieleń, błękit, ugier, niewielkie akcenty różu na dachach domów. Kontur poszczególnych elementów, niekiedy szeroki, i dosadne określenie wszystkich kształtów w niezbyt udany sposób współgra z tymi delikatnymi barwami. Ze znacznie większym wyczuciem Duninówna harmonizuje niewielkie płaszczyzny mocnych, zde-

\footnotetext{
${ }^{61}$ Młoda chłopka trzymająca na ręku dziecko w powijakach z Præedmieścia jest przedstawiona w typie Matki Boskiej z Dzieciątkiem. Szwačka to portret kobiety - każdej kobiety, z dowolnego czasu, która zajmuje się szyciem. Rabini - portret Żydów w bardzo bliskim kadrze na tle zabudowań miasteczka; dziewczyna czytająca młodszemu rodzeństwu i ich matka piorąca w balii to temat świadomie prymitywizującego drzeworytu $W$ ižbie.

${ }^{62}$ M. Wallis, Wystany. Maria i Zygmunt Duninowie (Zachęta), „Wiadomości Literackie” 1936, nr 43, s. 5.
} 
cydowanych barw z rozległymi czerniami, co odzwierciedla drzeworyt Wenecja-karnawał. Kompozycję wzbogaca żywa szmaragdowa zieleń i karmin, rozłożone jakby mimochodem, z nonszalancja, tylko po to, by podkreślić nastrój nokturnu. Sposób zastosowania barwy w tych pracach jest dowodem, że żywiołem Duninówny była jednak poetyka czerni i bieli. Barwa w jej grafice sprawdzała się jedynie w niewielkim zakresie o ile była drobnym akcentem przykuwającym wzrok, zwracającym uwagę na wybrany motyw (Taniec, Przed lustrem), tłem (wspomniany cykl Żywioly) lub elementem dekoracyjnym (Zwycięca, cykl Królón), a nie współdecydującym o całości, szczególnie w pejzażu ${ }^{63}$. Jeżeli już stosowała kolor, to po prostu kolorowała odbitki ręcznie (Madonna), a wtedy kompozycje nabierały nieco archaicznego charakteru. Tylko kilka drzeworytów odbijanych było z tylu klocków, ile barw na odbitce.

Wiktoria Goryńska za cezurę dwóch różnych okresów w drzeworytniczej twórczości Duninówny uznała jej kilkumiesięczną wizytę w Pary$\dot{z} u^{64}$. Wyróżniki tego własnego, dojrzałego stylu w drzeworycie dostrzegła $\mathrm{w}$, ,śmielszym rysunku i bardziej swobodnym ujęciu [...] czarne powierzchnie ożywają biel już nie jest płaska, lecz wydaje się świecić i migotać w cieniu. Akwarium jest tego dobrym przykładem"65. Wspomniane Akwarium (1932) jest jednym z najlepszych drzeworytów Duninówny. Ujęta z profilu dziewczynka wpatruje się w wodny świat rybek, muszli i wodorostów. Przykłada dłoń do szyby i na chwilę staje się jego częścią. Szyba akwarium odbija twarz dziewczynki en face - jest to odbicie „przełamane” pionowym kantem na styku ścianek prostopadłościennego akwarium - twarz jest półczarna, półbiała. Rybi pyszczek - naprzeciwko ust zapatrzonej dziewczynki jest analogicznym przykładem (do omówionych dalej ludzi i szympansów w zoo) poszukiwania relacji, ale także poetyckim zapisem możliwości przenikania się światów. Zastanawia, czy intencją artystki było, aby widz postrzegał i sylwetę dziewczynki i jej odbicie w szybie jako równie realne, namacalne?

${ }^{63}$ Niezbyt udany pejzaż w linorycie barwnym ze zbiorów graficznych Zakładu Narodowego im. Ossolińskich.

${ }^{64}$ W. J. Goryńska, Contemporary wood-engraving..., p. 344.

65 Ibidem. 
Zainteresowanie Marii Duninówny tematyką rodzajową szło w parze z częstotliwością przedstawiania scen z ogrodu zoologicznego ${ }^{66}$. Zwierzęta z zoo i ludzie usytuowani często w tej samej przestrzeni wchodzą ze sobą w relacje na różnych płaszczyznach narracyjnych; często artystka przydaje zwierzętom ludzkie cechy zgodnie z wzorcem ezopowych bajek, często zamienia role obserwujących i obserwowanych. W drzeworycie Ogród zoologiczny (ok. 1931) szympansy i ludzie oglądaja siebie nawzajem. Wyraziste sa zarówno typy ludzi, jak i małp. Graficzka obrazuje tu cała gamę zachowań postaci - od obojętności (elegantki na pierwszym planie, która przeglądając się w lusterku, zajęta jest tylko soba), poprzez nawiązanie kontaktu wzrokowego (postać w czapce i tygrys spoglądają na siebie), komunikację zwierząt (zwrócona do siebie para małp w tle), po fizyczną bliskość człowieka i zwierzęcia (ujęty z profilu mężczyzna gra z małpami w karty).

Patrząc na drzeworyty Duninówny z wizerunkami zwierząt, można odnieść wrażenie, że spędzała ona sporo czasu w warszawskim zoologu, studiując nie tylko ruchy, mimikę i zachowanie zwierząt, ale także reakcje ludzi obserwujących zwierzęta. Artystka obserwuje otoczenie i utrwala refleksje w drzeworycie, operując z dużym wyczuciem wysepkami bieli zazębiającymi się z plamami czerni; stają się one adekwatnymi formami dla opisu sytuacji, ale i komentarzami rzeczywistości. Duninówna w omówionym wyżej drzeworycie nie zadaje sobie trudu różnicowania faktury; dominuja tu czarne płaszczyzny, gdzieniegdzie przy konturze wzbogacone krótkimi żłobinami w różnych kierunkach. Bogatszy fakturowo jest drzeworyt Szympans na spacerze (1933), gdzie drobna siateczka skrzyżowanych cięć modeluje sylwetę dziewczynki prowadzącej szympansa (łapę małpy trzyma w swej dłoni), a drobne draśnięcia prowadzone w różnych kierunkach określają futro ma1py. Smycz zwierzęcia zwisa luźno, wręcz nonszalancko, widać po swobodnym ruchu obu postaci, że taki spacer w znajomym otoczeniu jest rutyna, ale także czymś więcej - pewną zażyłością dziewczynki i małpy (kto kogo prowadzi? W drzeworycie $W$ zoologu (ok. 1931) obserwuja się wzajem-

${ }^{66}$ Jak zauważył W. Husarski, ,powstanie w Warszawie Ogrodu Zoologicznego zwróciło uwage artystów naszych na plastyczno-dekoracyjne wartości zwierząt i ptaków egzotycznych”. (Rewia malarstwa wspótçesnej Polski, wystawa IPS Salon Zimowy, „Express Poranny” z 19 XII 1933, s. 6). 
nie ludzie i dwa słonie górujące nad otoczeniem; dzieli ich tylko niewysoki płotek i można odnieść wrażenie, że role oglądanych i oglądających zmieniają się, ulegają odwróceniu. Duninówna przedstawiała również wielbłą$\mathrm{dy}^{67}$ i scenki cyrkowe ${ }^{68}$.

Bliska Duninównie tematyka rodzajowa reprezentowana była także przez prace, które nie zachowały się w zbiorach publicznych, a znane sa z katalogów wystaw (Karuzela, Teatr amatorski). Animalistyka i wątki dnia codziennego, ale także sposób ich ujęcia, humorystyczny, ironiczny przywołuje na myśl prace amerykańskiej graficzki tworzącej w tym samym czasie, ale w technice litografii, Mabel Dwight (1876-1955). Prace obu artystek ujawniaja zbliżony sposób postrzegania świata, odczuwania i formułowania przekazu. Dla obu graficzek impulsem do podjęcia tematu było interesujące je miejsce, w którym mogły spędzić sporo czasu. W pierwszym przypadku był to ogród zoologiczny, w drugim - nowojorskie Aquarium, istniejące od $1896 \mathrm{r}$.

Duninówna tworzyła w drzeworycie także akty i półakty wydobyte z tła lapidarnymi cięciami dłutka (Akt, Prz̨ed lustrem), portrety (Róża Kachane), kilka widoków miast i pejzaży (Rynek, w Kamieńcu Litenwskim, Cerkiewka w Czortkowie, Pejzà் podhalański I, II). Tematykę religijną reprezentuja przede wszystkim drzeworyty kolorowane akwarelą: Matka Boska z Dqieciatkiem (na tle panoramy miasta) z 1926 r., Maria csytajaca (1937), kilka wersji Świętego Huberta ${ }^{69}$, Stygmatyzacja św. Franciszka (1927) oraz drzeworyt czarno-biały $W$ drodze na Golgote (1937). Drzeworyty o motywach sportowych wykonane były prawdopodobnie specjalnie na wystawę $e^{70}$, nigdy wcześniej (i później) nie pojawiły się w jej pracach tego typu motywy. Maria

${ }^{67}$ Drzeworyt Wielbłady jest studium matki z młodym; realistycznym, wydobywającym charakterystyczne cechy sylwety tych zwierząt i faktury ich sierści.

${ }^{68}$ W drzeworycie W cyrku - kulisy (1938) artystka pokazuje świat nie jako widz spektaklu, ale z perspektywy osoby uczestniczącej, dopuszczonej za kulisy, gdzie czekają na swój występ mały szympans, klown i karzeł, woltyżerka z końmi. Graficzka otwiera także widok na arenę z żonglerem i widownię. Czerń ma tu znacznie mniejszy udział niż w pozostałych pracach artystki - zrównoważona jest pół na pół biela, tak jak w innych drzeworytach wykonanych około 1938 roku.

69 Wcześniejszy z 1926 r., kolejny wykonany przed 1936 r.

${ }^{70} \mathrm{Na}$ wystawę Sport w sætuce Maria Duninówna zgłosiła siedem drzeworytów o tych samych wymiarach. 
Grońska $^{71}$ wymieniła i scharakteryzowała trzy drzeworyty (Rzut dyskiem, Skijöring i Kon w skoku) z siedmiu, które artystka wykonała w 1936 r. Były one także prezentowane na wystawie indywidualne ${ }^{72} \mathrm{w}$ TZSP w tym samym roku i najwyraźniej zapowiadały nowy etap poszukiwań graficzki ${ }^{73}$. Krytyczki zgodnie podkreśliły dynamikę, swobodę tych kompozycji i umiejętne działanie światłocieniem, przełamujące dotychczasową płaskośćc ${ }^{74}$, jakby podejmując nowy temat, kojarzący się z ruchem, dynamika, witalnością. Maria Dunin poczuła się zobligowana do ujawnienia nowego bogactwa środków i możliwości wydobytych z warsztatu drzeworytniczego. Drzeworyty artystki z 1938 r.: Pastusøkea (dziewczyna z krowami), wspomniany już drzeworyt Cyrk - za kulisami, a także prace wysłane na wystawę nowojorską sa świadectwem tej przemiany. Ostatnie znane dzieła ujawniają nowe myślenie artystki o drzeworycie - nie kategoriami płaszczyzn, ale brył i określania form światłocieniem. Być może właśnie w takim kierunku ewoluowałaby twórczość Marii Dunin, ale wybuch II wojny światowej położył kres jej działalności. Nie wiadomo tylko, czy dlatego, że świadomie zarzuciła tworzenie (z sobie tylko wiadomych powodów lub okoliczności), czy z powodu śmierci.

Zagadkowa jest data śmierci tej artystki, podawane są bowiem dwie: 1939 i 1986 rok. Maria Grońska ${ }^{75}$ przygotowując do druku Nowoczesny drzeworyt polski w 1970 r., na stronie 183 tekstu podała, że artystka nie przeżyła

71 „Cykl drzeworytów o tematyce sportowej [...] komponowany jest z prostotą i swoboda; uproszczona jest także faktura rycin” (Maria Grońska, Nowoczesny dræeworyt polski, op. cit., s. 183.)

72 Kolekecje prac Marii Dunin, Zygmunta Dunina, s. 19, 21.

73 Żadnej odbitki nie odnalazłam w polskich czy zagranicznych zbiorach publicznych.

74 Podhorska-Okołów podkreśliła „rozmach i naturalność ruchu, niekłamaną dynamikę ciała ludzkiego - większą swobodę i szerokość faktury" (S.P.O. [S. Podhorska-Okołów], Zygmunt i Maria Dunin, „Bluszcz” 1936, nr 39, s. 13.), Nela Samotyhowa zaakcentowała przemianę w graficznej twórczości Duninówny: „Ostatnim wyrazem ciekawej ewolucji tej artystki sa plansze na temat sportu, dynamiczne, świetliste i światłocieniowe, o kreskowaniu subtelnie zagęszczonym, wydobywającym i akcentującym bryłę. Sylwetkowość lat poprzednich została w nich pokonana” (N. Samotyhowa, W'śód dzieł sæ̨tuki, „Praca Obywatelska” 1936, nr 19, s. 11).

75 M. Grońska, Nowoczesny dræeworyt polski..., 1971, s. 183, 409; eadem, Grafika w kesiażce..., 1994, s. 225 (w obu publikacjach jako data śmierci podany rok 1939 ze znakiem zapytania). 
wojny; powtórzyła tę informację w kolejnej publikacji ${ }^{76}$, podając hipotetyczną datę śmierci artystki jako 1939 rok (ze znakiem zapytania). Duninówna najwyraźniej została uznana za zmarła (lub faktycznie zmarła) w czasie II wojny światowej - figuruje w Słowniku artystów polskich ${ }^{77}$ obejmującym biogramy artystów zmarłych przed 1966 r. Irena Jakimowicz formułuje opinię o indywidualnej drodze, jaką w końcu odnalazła artystka, ,zbyt wcześnie przerwana niesprzyjającymi warunkami"78, jednak nie rozwija tej myśli. Rok 1986 z datą miesięczną i dzienną figuruje w nekrologach warszawskich $^{79}$ i taka data roczna powielana jest w nowszych publikacjach ${ }^{80}$, w których zawarto biogram graficzki. Czy rozbieżności wynikły z dezinformacji tużpowojennego okresu, czy z pomyłki wynikającej z popularnych nazwisk artystki (i rodowego ${ }^{81}$ i tego po mężu) zestawionego z często nadawanym imieniem? Zakładając, że artystka przeżyła II wojnę światowa, jej działalność po 1945 r., jeżeli w ogóle tworzyła ${ }^{82}$, pozostaje nieznana; być może w czasie wojny lub tuż po wyjechała z kraju, ale to też nie tłuma-

76 M. Grońska, Grafika w kesiażce, tece i albumie, Wrocław 1994.

77 Stownik Artystón Polskich, op. cit., t. I, s. 123-125, hasło oprac.: H. Kubaszewska, brak daty śmierci artystki.

78 I. Jakimowicz, Pieć wiekón grafiki polskiej, Warszawa 1997, s. 157.

79 Nekrologi warszawskie (zakładając, że artystka zmarła w Warszawie) podają następujace daty śmierci osob o takim imieniu i nazwisku: Marii Dunin (16.11.1943) i Marii Piotrowskiej (rodowe nazwisko: Dunin): 06.08.1986 zob. http://www.nekrologi-baza.pl/zlista/306. Zakładając, że dane w warszawskiej bazie nekrologów dotyczą faktycznie tej artystki (brak podanej daty urodzenia umożliwiającej weryfikację), od 1938 r. w katalogach wystaw występuje pod nazwiskiem Dunin-Piotrowska), brakuje jakichkolwiek informacji o jej losach powojennych. Żadnych informacji biograficznych na temat artystki, szczególnie jej losów powojennych nie mają członkowie rodu Duninów (korespondencja autorki z Mirosławem Dunin-Sulgostowskim, jednym z członków Komisji Historycznej Stowarzyszenia Rodu Duninów ze stycznia 2014).

${ }^{80}$ Grafika polska. Estampes polonaises. Polish Prints 1918-1939, Montreal - Kraków wyd. z 1999 i 2002; Muzeum Polskie w Ameryce. Zbiory grafične, red. naukowa M. Czubińska, Kraków 2008.

81 Niestety bez przydomka, identyfikującego gałąź rodu jak jest w wielu przypadkach członków rodu Dunin (np. tworzący w tym samym czasie, również grafikę, artysta Mieczysław Dunin-Bartodziejski), co może ułatwiłoby identyfikację.

${ }^{82}$ Jeśli przeżyła, nie ma dokumentacji czy wzmianek o jej późniejszej twórczości prezentowanej publicznie (w Zakładzie Badań Podstawowych Historii Sztuki - Dokumentacji Plastyki Współczesnej Instytutu Sztuki PAN nie ma teczki artystki ani żadnych informacji na jej temat, co jednak nie przesądza o jej istnieniu czy nieistnieniu). 
czy braku śladów. Z kolei jej brat, Zygmunt Dunin zmarł na gruźlicę prawdopodobnie przed 1939 r. Takie „białe plamy” boleśnie obecne w biografii obojga twórców znaczą też ich dorobek; mam tu na myśli prace zaginione, znane, jak na ironię losu, tylko z tytułów lub reprodukcji w czasopismach, a przecież drzeworyty istniejące w pewnej liczbie odbitek statystycznie mają większe szanse na przetrwanie choć jednej z nich niż obraz. Na rynku sztuki w ostatnich latach pojawiło się zaledwie kilka drzeworytów Mariii ${ }^{83}$ i jeden Zygmunta ${ }^{84}$. Wydaje się, że dziś, ze strzępów informacji i tropów można konstruować tylko hipotetyczną tkankę losów obojga artystów, licząc, że może ktoś z rodziny, powinowatych lub potomków osób, którzy znali rodzeństwo artystów Marii Dunin-Piotrowskiej i Zygmunta Dunina, odnajdzie w pamięci ślady ich obecności.

\section{Summary}

\section{Graphic oeuvres of Maria Dunin-Piotrowska and Zygmunt Dunin}

This article discusses to the work, graphic art and drawings, of the siblings, Maria Dunin-Piotrowska and Zygmunt Dunin created in the 1930s. The Dunins came from Kamyanets-Podilsky, and both graduated from Fine Arts Academy in Warsaw, and later were affiliated with the Association of Polish Graphic Artists. Their major form of artistic expression was woodcut; Zygmunt Dunin also dealt with drawing, especially its satirical variety. The oeuvres of both artists to great extent relied on dark humor and grotesque presentations of reality which is illustrated by both of them employing jet-black as the primary mode of expression. Only few of the artistic achievements of Maria Dunin survived till today. She was a student of Władysław Skoczylas, and a member of Ryt [Engraving] a graphic artists' association, and one of the most talented Polish interwar female graphic artists. Her life after 1939 mostly remains a mystery, and the work of her younger brother, Zygmunt, a graphic artist, an illustrator, and a cartoonist is yet to be analyzed and researched. The works by either of them that have survived to this

\footnotetext{
83 Drzeworyt prezentowany pod tytułem Królewna i smok (oryginalnie Zuycięca) z 1925 r. w krakowskiej DESie; Św. Hubert z 1926 r. na aukcji z IV 2009; Stygmatyzacja św. Franciszka (1927) i Turniej (1928) przez krakowski Nautilus, aukcja nr 38 z 18 V 2013; W drodze na Golgote (1937) aukcja Nautilusa z 15.12.2012 r.

${ }^{84}$ Zaułek (Katedra), 1932, drzeworyt prezentowany na aukcji krakowskiego Nautilusa z 15.12.2012 r.
} 
day in public records as well as those that are known for their reproductions in magazines and pre-war exhibitions' catalogues represent only a small fraction of the siblings' tremendous achievements. I combine an attempt to determine the distinctiveness of media and artistic means they both employed as artists with the mode they influenced each other in their artistic endeavors. The artistic conducts of Maria Dunin and her younger brother, Zygmunt, share certain traits: the inclination towards the grotesque and dark humor, although the woodcuts by Maria did not highlight the grim aspects of reality or the ugliness of human physiognomy to the extent the works by her brother did. The radicalism visible in his drawings originated in the sharpened look, and the sensitivity to ugliness, as well as reality depicted as mirrored in a distorting mirror. The last known works by both artists are dated 1937 and 1938 . 


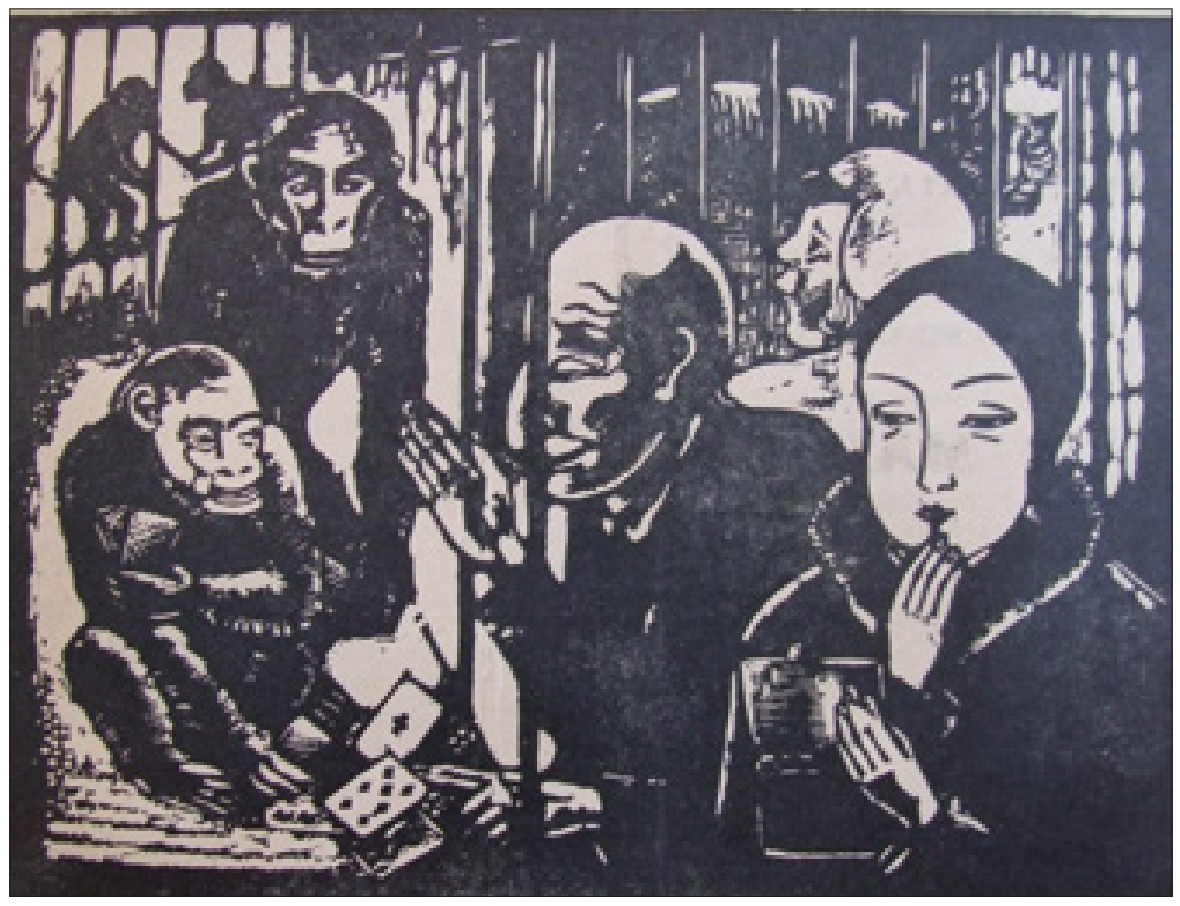

1. Maria Dunin, Ogród zoologiczny, ok. 1931, drzeworyt, reprod. w: „Kobieta Współczesna” 193, nr 16, s. 1 


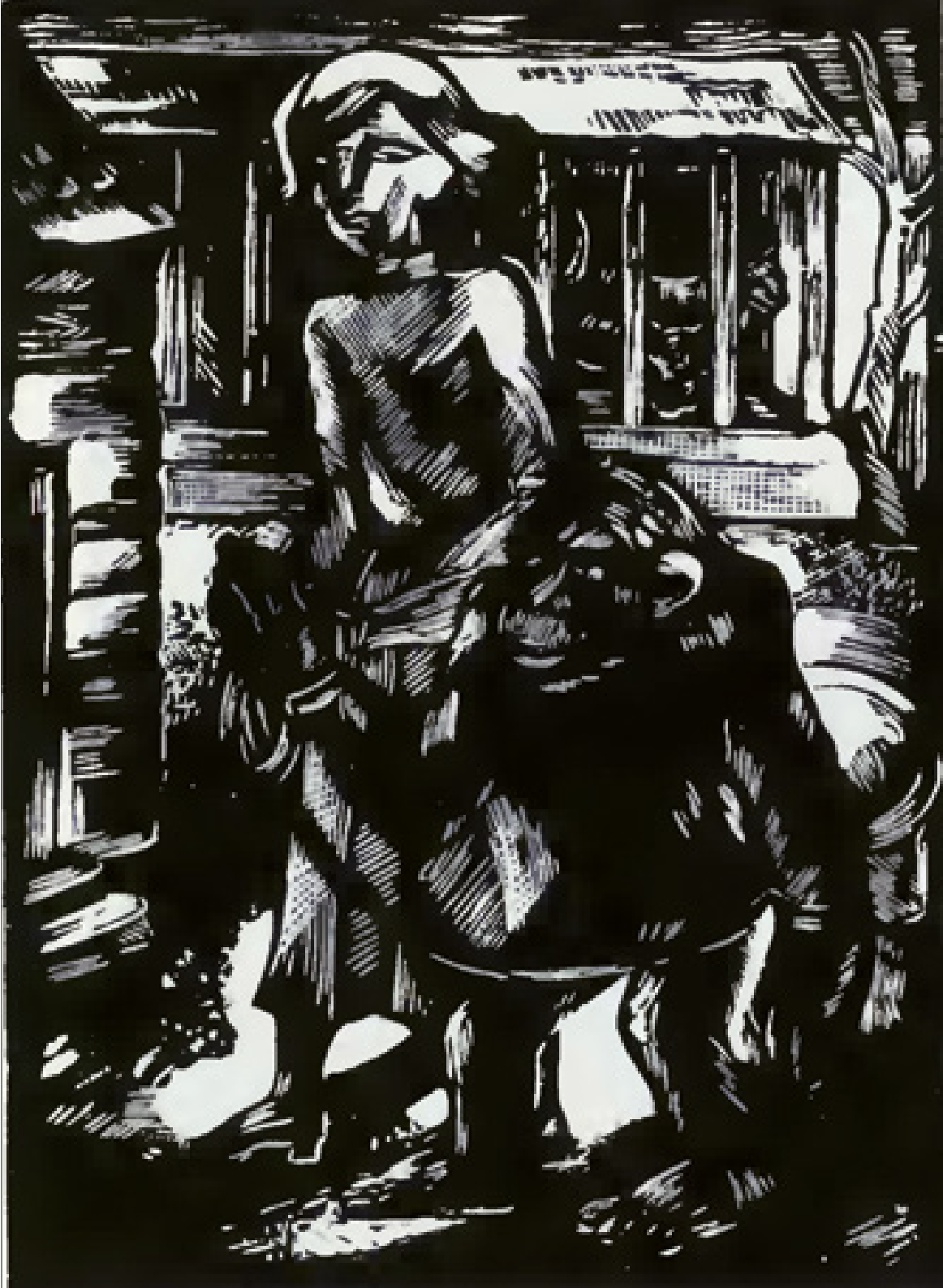

2. Maria Dunin, Saympans na spacerze, 1933, drzeworyt, reprod. w: „Plastyka” 1936, nr 1, s. 158 


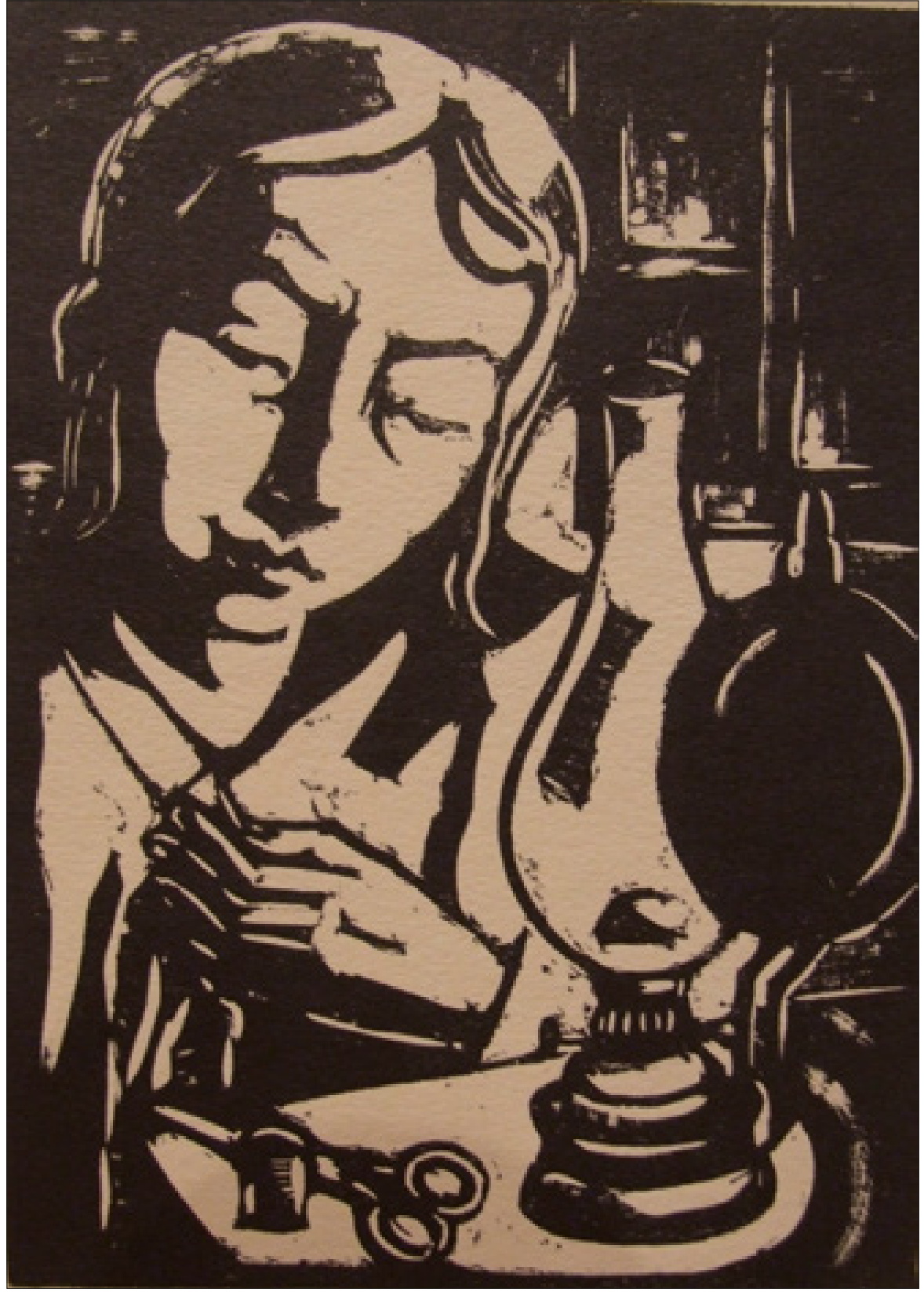

3. Maria Dunin, Krawcowa, lata 30., drzeworyt, zbiory Muzeum Narodowego w Warszawie 


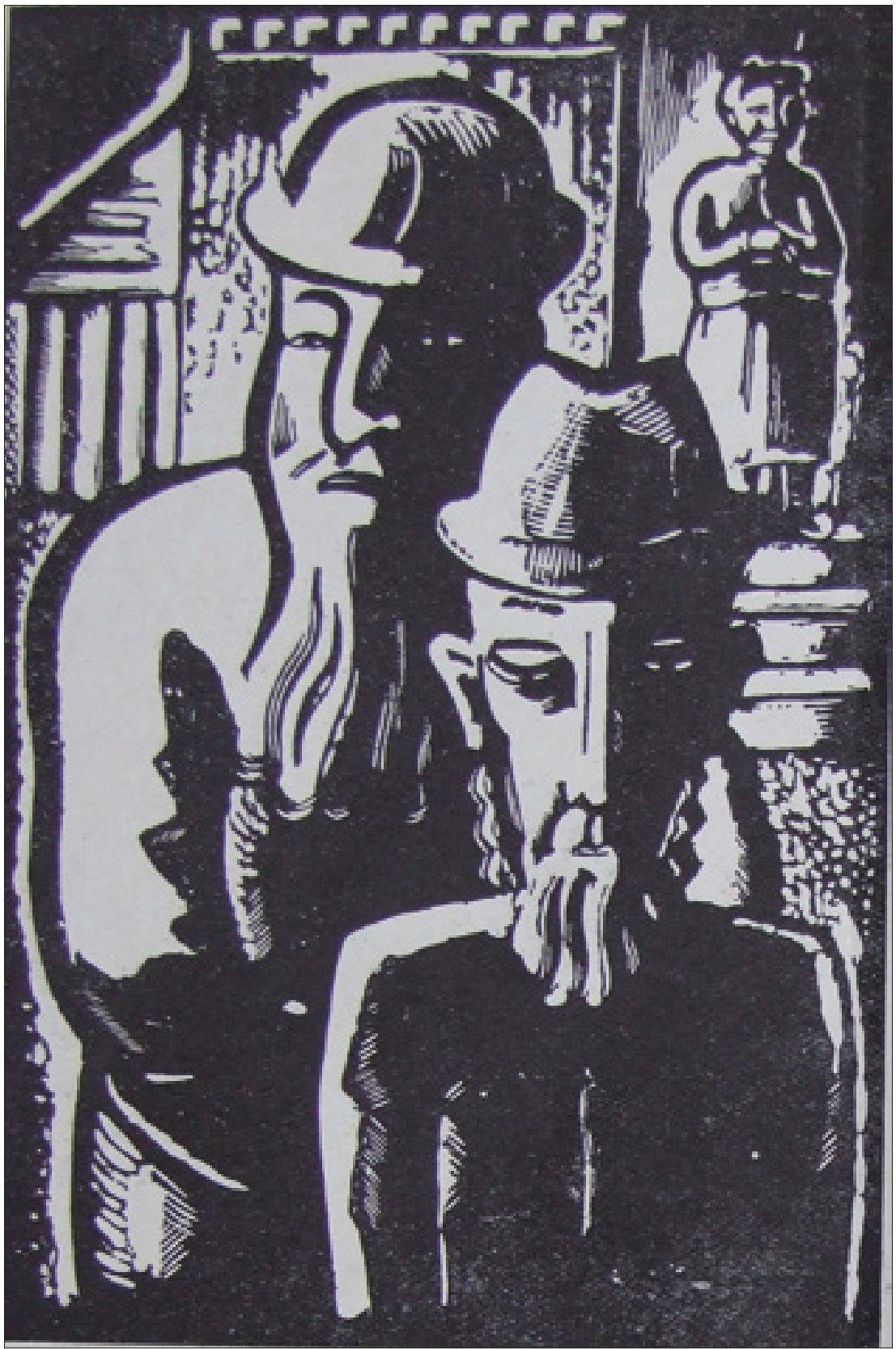

4. Maria Dunin, Rabini, ok. 1933, drzeworyt, reprod. w: „Kobieta Współczesna” 1933, nr 17 , s. 334 


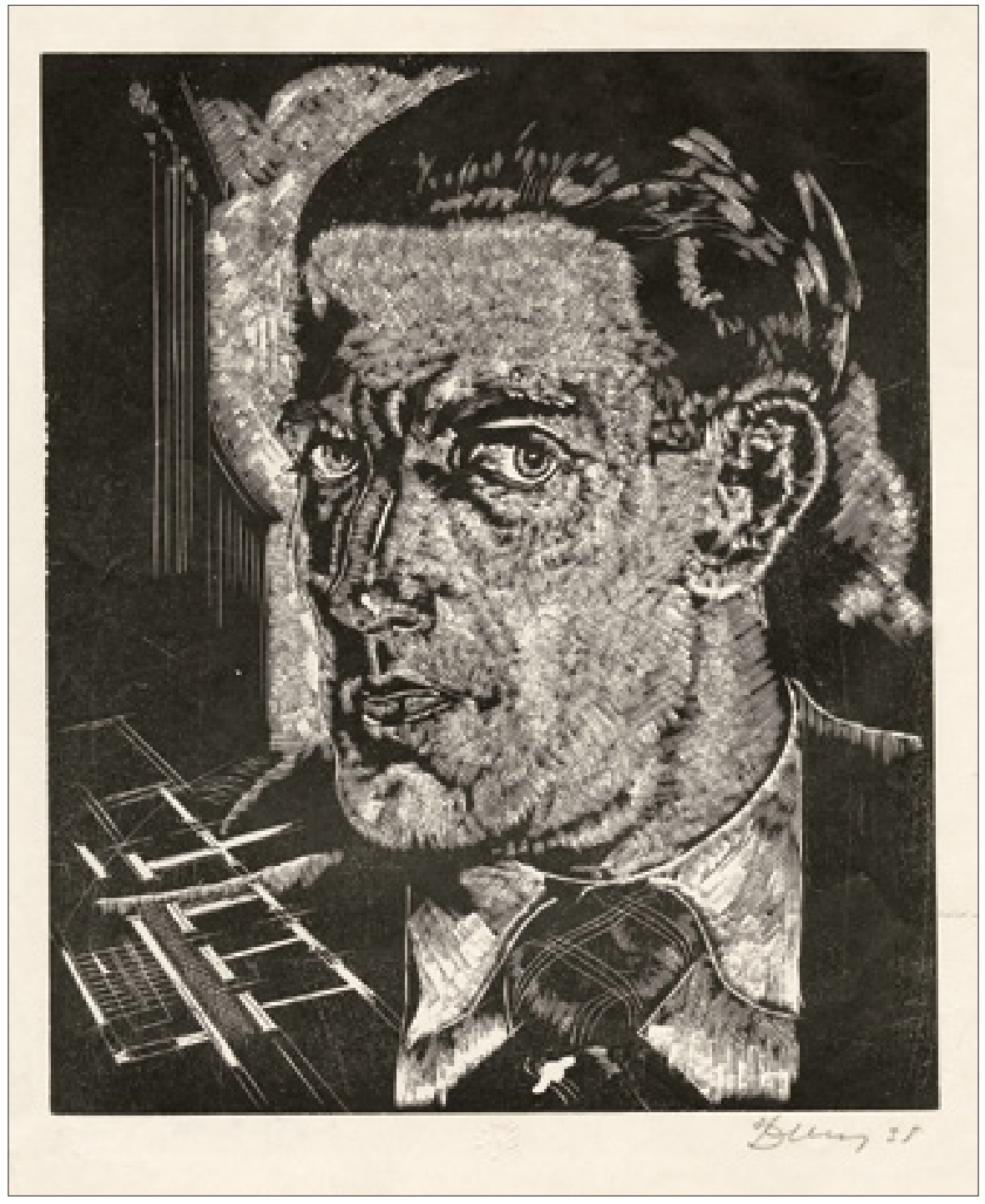

5. Zygmunt Dunin, Autoportret, 1935, drzeworyt, ze zbiorów Gabinetu Grafiki Muzeum Książąt Lubomirskich Zakładu Narodowego im. Ossolińskich 


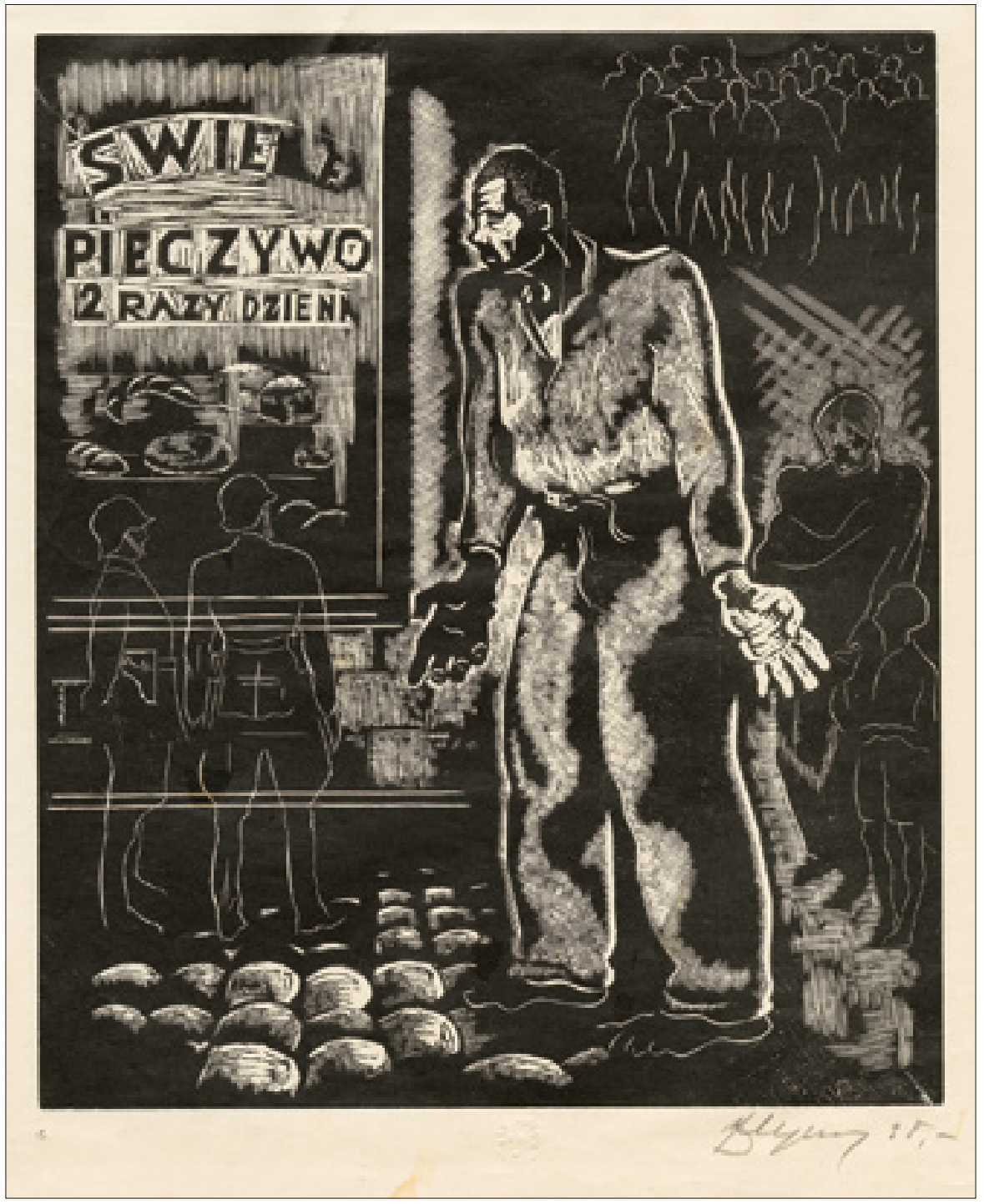

6. Zygmunt Dunin, Demonstracja bearobotnych, 1935, drzeworyt, ze zbiorów Gabinetu Grafiki Muzeum Książąt Lubomirskich Zakładu Narodowego im. Ossolińskich 


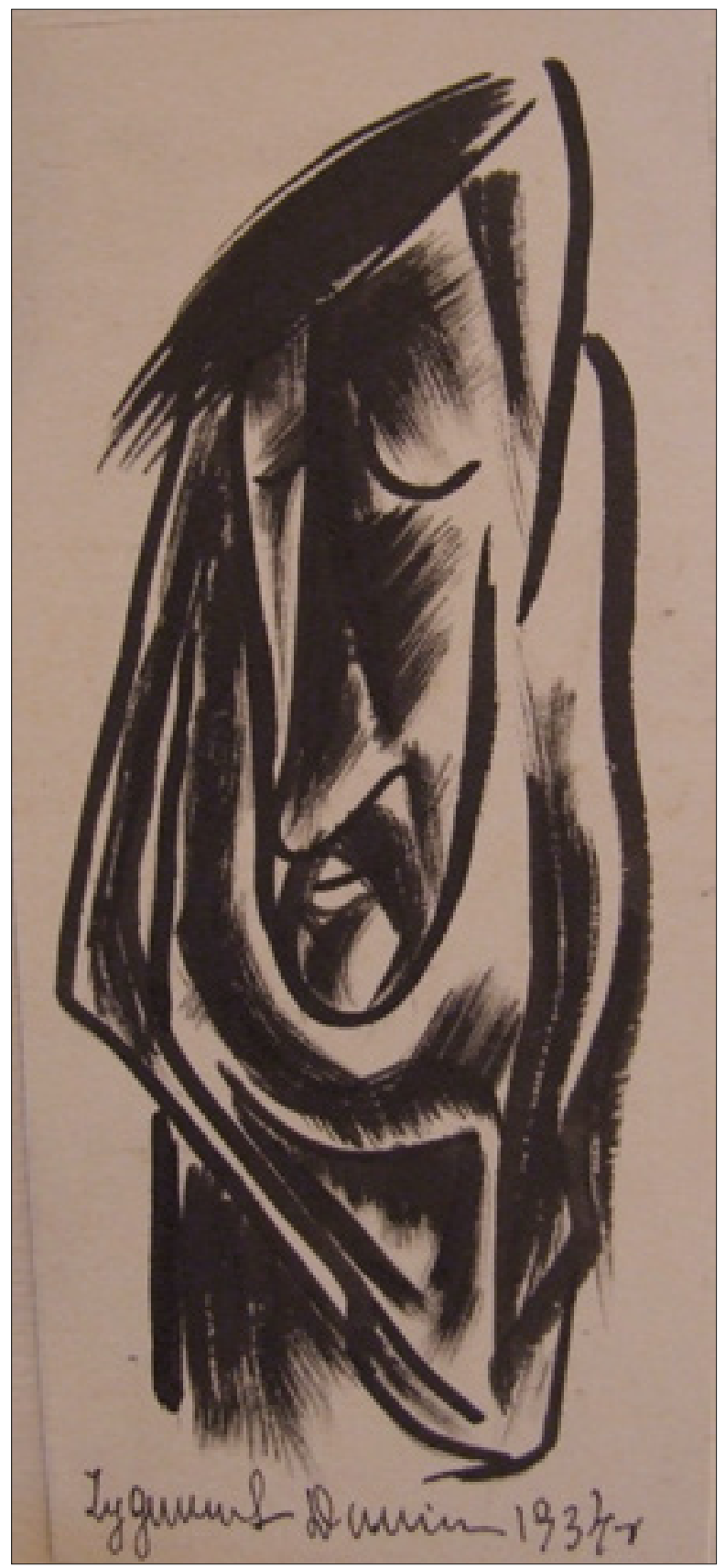

7. Zygmunt Dunin, rysunek tuszem, 1934, ze zbiorów specjalnych IS PAN 


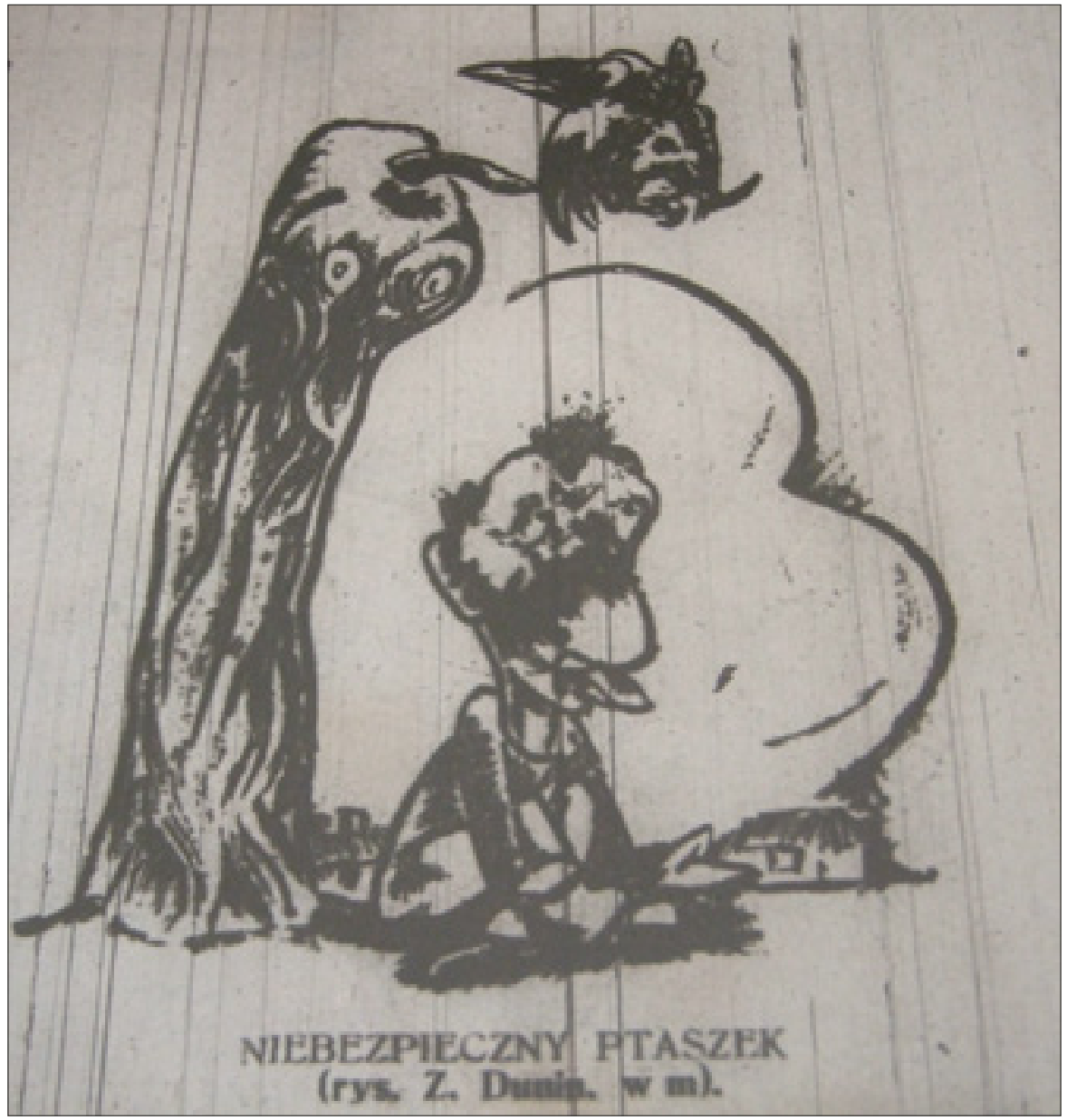

8. Zygmunt Dunin, Nieberpiečny ptaszeek, rysunek w: „Cyrulik Warszawski” 1932, nr 35, s. 7 